\title{
Co-pigmentation of Anthocyanin Jamblang Fruit (Syzygium cumini) with Acetic Acid and Alum
}

\section{Chintia N. Barani, *Siti Nuryanti, \& Paulus H. Abram}

Program Studi Pendidikan Kimia/FKIP - Universitas Tadulako, Palu - Indonesia 94119

Received 29 June 2021, Revised 28 July 2021, Accepted 24 August 2021

doi: $10.22487 /$ j24775185.2021.v10.i4.pp237-246

\begin{abstract}
This study aimed to determine the effect of temperature on the stability of anthocyanin jamblang after copigmentation with acetic acid and alum. The extraction of Jamblang fruit used the maceration method with $n$ hexane, ethyl acetate, and ethanol-HCl $0.5 \%$ solvents. The total anthocyanin obtained was $70.64 \mathrm{mg} / \mathrm{L}$. Anthocyanin of jamblang fruit was co-pigmented with acetic acid and alum in a concentration of 2.5\%; 5\%; 7.5\%; and $10 \%$, then be heated at various temperatures and heating times. At a temperature of $80{ }^{\circ} \mathrm{C}$ for 150 minutes, every 30 minutes, absorbance was measured. At a temperature of $60^{\circ} \mathrm{C}$, the heating was carried out for 225 minutes, and every 45 minutes, absorbance was measured. At a temperature of $40^{\circ} \mathrm{C}$, the heating was carried out for 300 minutes, and every 60 minutes, absorbance was measured. Absorbance measurements were taken using a UV-VIS spectrophotometer. The results showed that co-pigmentation of anthocyanin occurred proved by shifting $\lambda$ max from $470 \mathrm{~nm}$ (unco-pigmented extract) to $500 \mathrm{~nm}$ (co-pigmented extract acetic acid) and $540 \mathrm{~nm}$ (co-pigmented extract alum). Acetic acid and alum co-pigments maintained the stability of anthocyanin jamblang at a heating temperature of $60{ }^{\circ} \mathrm{C}$. It can be seen from decreased absorbance, which is not so significant compared to the decrease at temperatures of 40 and $80^{\circ} \mathrm{C}$, accompanied by anthocyanin's fading color, which is co-pigmented with acetic acid and alum during the heating process.
\end{abstract}

Keywords: Syzygium cumini, anthocyanin, co-pigmentation, acetic acid, alum, UV-VIS spectrophotometer

\section{Introduction}

Anthocyanins are the most important and most widespread dyes in plants. Anthocyanins are solid and water-soluble pigments that cause almost all pink, peacock red, red, red, purple, and blue colors in leaves, flowers, and fruit in plants (Harborne, 1987). One of the plants that contain anthocyanins is the jamblang fruit. The characteristics of the jamblang fruit can be seen: green fruit when it is still raw and dark purple-black when fully ripe.

Anthocyanins are easily damaged when processing fruits and vegetables that contain these pigments. High temperature, increased sugar content, $\mathrm{pH}$, and ascorbic acid can affect the rate of anthocyanin breakdown (Nugraheni \& Mutiara, 2014).

Increasing the temperature of the manufacture and storage process can cause damage and rapid changes in anthocyanins through the stages of hydrolysis of the glycosidic bonds of anthocyanins and produce labile aglycones; The opening of the aglycone ring results in the formation of colorless carbinol and chalcone groups (Ibnu et al., 2013).

Therefore, it is necessary to maintain the stability of anthocyanins against temperature. One of the efforts that can be done to increase the strength of anthocyanins is copigmentation (Sari et al., 2005). Copigmentation increases the stability of anthocyanins by forming complex bonds between copigment compounds and anthocyanins, thereby reducing the interaction of anthocyanins with water molecules that cause anthocyanin degradation (Gozalez-Menzano et al., 2009).

Copigmentation is the interaction between the anthocyanin structure with other molecules such as metals $\left(\mathrm{Al}^{3+}, \mathrm{Fe}^{3+}, \mathrm{Sn}^{2+}, \mathrm{Cu}^{2+}\right)$ and other organic molecules such as flavonoids (flavones, flavanones, flavonols), and so on. The presence of copigmentation between anthocyanins with metals and other organic molecules increases the color stability of anthocyanins, produces a lighter color, and is protected from oxidation (Boulton, 2001). It happens because of the interaction between the anthocyanin structure with other molecules called copigment compounds, namely flavonoids (flavones

\footnotetext{
*Correspondence:

Siti Nuryanti

e-mail: sitinoer_untad@yahoo.com

(c) 2021 the Author(s) retain the copyright of this article. This article is published under the terms of the Creative Commons Attribution-NonCommercial-ShareAlike 4.0 International, which permits unrestricted non-commercial use, distribution, and reproduction in any medium, provided the original work is properly cited.
} 
and flavonols) and other polyphenols (phenolic acids), alkaloids (caffeine), amino acids, organic acids, nucleotides, polysaccharides, metals $\left(\mathrm{Al}^{3+}\right.$, $\left.\mathrm{Fe}^{3+}, \mathrm{Sn}^{2+}, \mathrm{Cu}^{2+}\right)$, and even the anthocyanins themselves. The interaction of these components can occur through intermolecular copigmentation, intramolecular copigmentation, metal complexation, or copigmentation with the substance itself (Munawaroh et al., 2017). Copigments are compounds used in copigmentation. According to Syafitri (2015), color generating compounds or pigments that can be used are an alum, lime, whiting, tunjung, coconut sugar, palm sugar, vinegar, tamarind.

The copigments used in this study were acetic acid and alum. The use of acetic acid is because anthocyanins are stable in acidic conditions. Acetic acid is a compound that includes organic acids. According to Munawaroh et al. (2015), organic acids can be used as copigments for anthocyanins. Acetic acid has an acidity constant of $1.8 \times 10^{-5}$ (Siswoyo, 2009). Slightly acidic conditions will increase the intensity of the anthocyanin color, making it red (Nugraheni \& Mutiara, 2014). The use of alum is due to $\mathrm{Al}^{3+}$ metal which is thought to form stable complexes with anthocyanins. Alum is a group of hydrated double salts with the chemical formula $\mathrm{Al}\left(\mathrm{SO}_{4}\right)_{2} \cdot 12 \mathrm{H}_{2} \mathrm{O}$, non-toxic and harmful to health, with a $\mathrm{pH}$ of 9 and an acidity degree of 8 (close to normal). Alum can change the color of anthocyanins to bluish by forming complexes (Syafitri, 2015).

\section{Methods}

The tools used in this study were a set of glassware, blender, analytical balance, Whatman no. 1 filter paper, shaker, centrifuge, Buchner funnel, water bath, and UV-Vis spectrophotometer, vials, dark bottles, rotary vacuum evaporator, stainless steel blade.

The materials used were jamblang fruit obtained from the city of Palu, n-hexane, ethyl acetate, $96 \%$ ethanol, $1 \mathrm{M} \mathrm{HCl}, \mathrm{pH} 1$ and 4.5 buffer, acetic acid with a concentration variation of $2.5 \% ; 5 \% ; 7.5 \% ; 10 \%$, alum with a concentration variation of $2.5,5,7.5$, and $10 \%$.

\section{Sample preparation}

Jamblang fruit samples to be studied, previously sorted or selected first. Jamblang fruit that will be used was a ripe jamblang fruit with dark purple fruit characteristics. Furthermore, the skin of the jamblang fruit is separated from the flesh using a stainless steel knife so that the skin of the jamblang fruit was ready for extraction.

\section{Sample extraction}

Anthocyanin extraction was carried out by the maceration method. The skin of the jamblang fruit, separated from the flesh of $500 \mathrm{~g}$, was cut into small pieces, put in a brown or dark-colored bottle. Then $2500 \mathrm{~mL}$ of $\mathrm{n}$-hexane was added, extracted by maceration for 24 hours. The extract was filtered with Whatman paper no. 1 through a Buchner funnel. The residue (dregs) is aerated to remove the solvent. The dry residue was extracted again with $2500 \mathrm{~mL}$ ethyl acetate for several hours. The extract was filtered, followed by aeration. Extract the dry residue with $0.5 \%(\mathrm{v} / \mathrm{v})$ ethanol- $\mathrm{HCl}$ for several hours and then filter. The filtrate was collected, then concentrated with a vacuum rotary evaporator at $60-65^{\circ} \mathrm{C}$ until a concentrated extract was obtained (Nuryanti et al., 2012).

\section{Measurement of total anthocyanin levels}

The total anthocyanin of jamblang fruit was measured using the extracted filtrate. Into two Erlenmeyer, $5 \mathrm{~mL}$ of each extract was added. The first Erlenmeyer was added with $5 \mathrm{~mL}$ of $\mathrm{pH} 1$ buffer, and the second Erlenmeyer was added with $5 \mathrm{~mL}$ of $\mathrm{pH} 4.5$ buffer. Both parts were measured for absorption at wavelengths of 510 and $700 \mathrm{~nm}$ using a UV-Vis spectrophotometer, then calculated the absorption and anthocyanin content of the sample (Ashari, 2010).

\section{Determination of maximum wavelength}

The maximum wavelength was determined for the unpigmented extract and the copigmented extract with acetic acid and alum. Each $1.5 \mathrm{~mL}$ of jamblang fruit peel extract without adding acetic acid and alum and sections added with $10 \%$ acetic acid and $10 \%$ alum were measured for absorption at a $200-700 \mathrm{~nm}$ wavelength to obtain the maximum wavelength of jamblang fruit extract. uncopigmented and copigmented with acetic acid and alum to be used for measurement (Nusantara et al., 2017).

\section{Copigmentation of jamblang fruit anthocyanins with acetic acid}

A total of $1.5 \mathrm{~mL}$ of anthocyanin extract of jamblang fruit peel was mixed with $20 \mathrm{~mL}$ of acetic acid with various concentrations of $2.5 \%, 5 \%$, $7.5 \%, 10 \%$ in a closed vial. Then tested its stability against temperature (Lestario \& Silvia, 2016).

For color stability test against temperature: The above vials were put in a water bath at 40,60 , and $80^{\circ} \mathrm{C}$. Heating was carried out for 300 minutes for a temperature of $40{ }^{\circ} \mathrm{C}$; every 60 minutes, the absorbance was measured. Heating to a temperature of $60^{\circ} \mathrm{C}$ was carried out for 225 minutes; every 45 minutes, the absorbance was measured. Heating to a temperature of $80{ }^{\circ} \mathrm{C}$ was carried out for 150 minutes; every 30 minutes, the absorbance was measured. The absorbance measurement was carried out at the maximum wavelength of the previously obtained acetic acid copigmented extract, $500 \mathrm{~nm}$. All measurements were carried out in duplicate.

Copigmentation of Jamblang fruit anthocyanins with alum (Lestario \& Silvia, 2016). A total of $1.5 \mathrm{~mL}$ of jamblang fruit anthocyanin extract was mixed with $20 \mathrm{~mL}$ of alum with various concentrations of $2.5 \%, 5 \%, 7.5 \%, 10 \%$ in a sealed vial. Then tested its stability against temperature. 
For color stability test against temperature: The above vials were put in a water bath at $40{ }^{\circ} \mathrm{C}$, $60{ }^{\circ} \mathrm{C}$, and $80^{\circ} \mathrm{C}$. Heating was carried out for 300 minutes for a temperature of $40{ }^{\circ} \mathrm{C}$; every 60 minutes, the absorbance was measured. Heating to a temperature of $60{ }^{\circ} \mathrm{C}$ was carried out for 225 minutes; every 45 minutes, the absorbance was measured. Heating to a temperature of $80{ }^{\circ} \mathrm{C}$ was carried out for 150 minutes; every 30 minutes, the absorbance was measured. At the maximum wavelength of the previously obtained copigmented alum extract, $540 \mathrm{~nm}$, the absorbance measurement was carried out. All measurements were carried out in duplicate.

\section{Stability test to temperature}

Absorbance data were obtained for copigmentation of jamblang fruit anthocyanins with acetic acid and alum at various temperatures, plotted against the heating time, one curve for each heating temperature, to see the degradation of anthocyanins with different concentrations of copigments, different temperatures, and the length of heating time.

\section{Results and Discussion}

\section{Jamblang fruit peel anthocyanin extract}

Extraction of jamblang fruit peel in this study using the maceration method. Maceration aims to attract anthocyanin compounds using anthocyanin solubility properties. This method considers the nature of the material's solubility (sample) to be extracted and the nature of anthocyanins that are easily degraded by heat. Jamblang fruit anthocyanin extraction uses three solvents with different properties: n-hexane, ethyl acetate, and $0.5 \%$ ethanol-HCl (Nuryanti et al., 2012).

Jamblang fruit anthocyanin extraction process was carried out in a container covered with aluminum foil. This is to avoid contact with light during the extraction process. According to (Basuki et al., 2005), the stability of anthocyanins is influenced by several factors, one of which is light. Jamblang fruit anthocyanin extraction uses three solvents with different properties: n-hexane, ethyl acetate, and $0.5 \%$ ethanol-HCl. The function of the $\mathrm{n}$-hexane solvent is to attract non-polar compounds contained in the sample according to the non-polar solubility of n-hexane. Ethyl acetate functions as a solvent that will attract semi-polar compounds from the sample according to their semi-polar solubility properties. The ethanol solvent is polar to attract polar compounds, especially anthocyanins. The addition of $\mathrm{HCl}$ aims for maceration in an acidic environment. (Nugraheni \& Mutiara, 2014) stated that anthocyanins are more stable in acidic solutions. $\mathrm{HCl}$ is the most effective type of acidifier. $\mathrm{HCl}$ can denature plant cell membranes and dissolve anthocyanin pigments out of cells (Kristiana et al., 2012).

Table 1. The color of the filtrate and residue extracted from the jamblang fruit peel

\begin{tabular}{|c|c|c|}
\hline Sample and Solvent & Filtrate Color & Residue Color \\
\hline Jamblang fruit skin and n-hexane & $\begin{array}{l}\text { Clear with a bit of purple liquid separated at the } \\
\text { bottom. }\end{array}$ & Deep purple \\
\hline Jamblang fruit peel and ethyl acetate & Clear yellow & Purple \\
\hline Jamblang rind and $0.5 \%$ ethanol- $\mathrm{HCl}$ & Purple & Pale purple \\
\hline
\end{tabular}

The filtrate resulting from maceration with $\mathrm{n}$ hexane, ethyl acetate, and $0.5 \%$ ethanol- $\mathrm{HCl}$ was collected, then concentrated with a vacuum rotary evaporator at $60-65^{\circ} \mathrm{C}$ until a concentrated extract they are using obtained. Using a vacuum rotary evaporator at $60-65^{\circ} \mathrm{C}$ aims to concentrate the extract. Because the solvents evaporate at that temperature, the anthocyanin extract obtained is concentrated. The solvent $\mathrm{n}$-hexane boils at a temperature of $60-70{ }^{\circ} \mathrm{C}$ (Utomo, 2016), ethyl acetate evaporates at a temperature of $77.1{ }^{\circ} \mathrm{C}$
(Azura et al., 2015), ethanol can evaporate at a temperature of $60^{\circ} \mathrm{C}$ (Zulfajri \& Muttakin, 2017).

\section{Total anthocyanin measurement}

Measurement of total anthocyanins was carried out using the $\mathrm{pH}$ difference method (Sutharut \& Sudarat, 2012). Based on the absorbance obtained from measurements using a UV-VIS spectrophotometer, the jamblang fruit skin sample contained $70.64 \mathrm{mg} / \mathrm{L}$ anthocyanins.

Table 2. Total anthocyanins of jamblang fruit extract

\begin{tabular}{|c|c|c|c|c|c|}
\hline \multirow{3}{*}{ Replication } & \multicolumn{4}{|c|}{ Absorbance } & \multirow{3}{*}{$\begin{array}{c}\text { Total } \\
\text { Anthocyanin } \\
(\mathrm{mg} / \mathrm{L})\end{array}$} \\
\hline & \multicolumn{2}{|c|}{$\mathrm{pH} 1$} & \multicolumn{2}{|c|}{$\mathrm{pH} 4.5$} & \\
\hline & $\begin{array}{c}\lambda 510 \\
\mathrm{~nm}\end{array}$ & $\begin{array}{c}\lambda 700 \\
\mathrm{~nm}\end{array}$ & $\begin{array}{c}\lambda 510 \\
\mathrm{~nm}\end{array}$ & $\lambda 700 \mathrm{~nm}$ & \\
\hline 1 & 2.050 & 1.689 & 0.408 & 0.874 & 69.05 \\
\hline 2 & 2.045 & 1.659 & 0.408 & 0.871 & 70.89 \\
\hline 3 & 2.049 & 1.647 & 0.407 & 0.867 & 71.97 \\
\hline \multicolumn{5}{|c|}{ Rata-rata } & 70.64 \\
\hline
\end{tabular}


The difference in $\mathrm{pH}$ used is at $\mathrm{pH} 1$ and $\mathrm{pH}$ 4.5. The $\mathrm{pH} 1$ was anthocyanin in the form of colored axanium, which represented the amount of anthocyanin and interfering compounds. At $\mathrm{pH}$ 4.5, anthocyanins were in hemiketal form, and there was a decrease in color intensity until they were colorless, so the absorption was a nuisance compound. The wavelength used to measure the absorption is wavelength 510 , the wavelength of cyanidin-3-glucoside. Cyanide-3-glucoside was used as standard. This is because the pigment is the most common anthocyanin pigment found in nature (Lee et al., 2005), while a wavelength of 700 $\mathrm{nm}$ is used as a correction factor (Supiyanti et al., 2010). Absorbance measurements were carried out three times. Repetition aims to reduce measurement errors so that data acquisition is accurate. Figure 1 shows the structure of anthocyanins at $\mathrm{pH} 1$ and $\mathrm{pH}$ 4.5 .

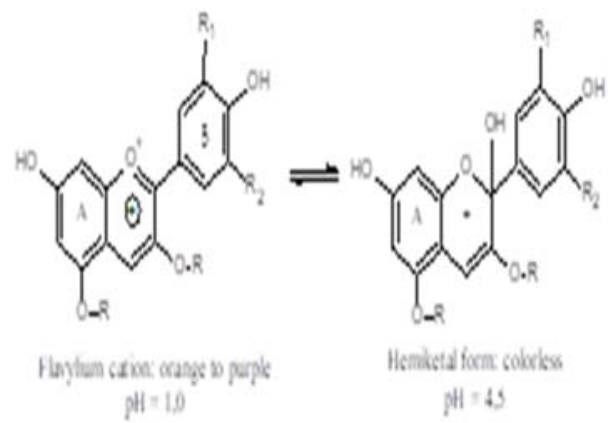

Figure 1. Anthosainin structure at $\mathrm{pH} 1$ and $\mathrm{pH} 4.5$

(Wrolstad et al., 2005)

\section{Determination of maximum wavelength}

The maximum wavelength measurement aims to see the complete absorbance shift of the copigmented extract. The maximum wavelength obtained was used to measure the anthocyanin copigmentation absorbance of jamblang fruit (Nusantara et al., 2017).

Table 3. Max anthocyanin extract of jamblang fruit

\begin{tabular}{lcc}
\hline \multicolumn{1}{c}{ Jamblang Fruit Extract } & Max $(\mathrm{nm})$ & Absorbance \\
\hline Not Copigmented & 470 & 2.873 \\
Copigmented with Acetic Acid & 500 & 2.252 \\
Copigmented with Alum & 510 & 1.538 \\
\hline
\end{tabular}

The maximum wavelength of anthocyanin extract is by the literature, which states that the characteristics of anthocyanins have a maximum wavelength range of 505-535 $\mathrm{nm}$ (Lestario, 2017).

The maximum wavelength measurement results showed a shift in the maximum absorbance of the uncopigmented extract with the copigmented extract with acetic acid. The shift occurs from the wavelength of $470 \mathrm{~nm}$ to $500 \mathrm{~nm}$. The same applies to extracts copigmented with alum. The shift occurs from the wavelength of $470 \mathrm{~nm}$ to $510 \mathrm{~nm}$. This shift is bathochromic. This shows that there is copigmentation between jamblang fruit anthocyanins with acetic acid and with alum.

Jamblang fruit anthocyanin copigmentation with
acetic acid
Copigmentation of jamblang fruit anthocyanins with acetic acid produces a red solution. The absorbance data of the anthocyanin copigmentation of jamblang fruit with acetic acid can be seen in the Tables 4-6.

Table 4. Copigmentation of anthocyanins with acetic acid at $40{ }^{\circ} \mathrm{C}$

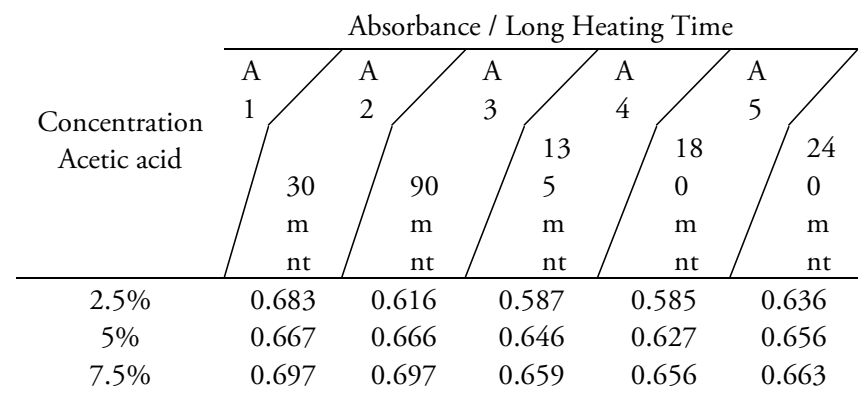


Table 5. Copigmentation of anthocyanins with acetic acid at $60{ }^{\circ} \mathrm{C}$

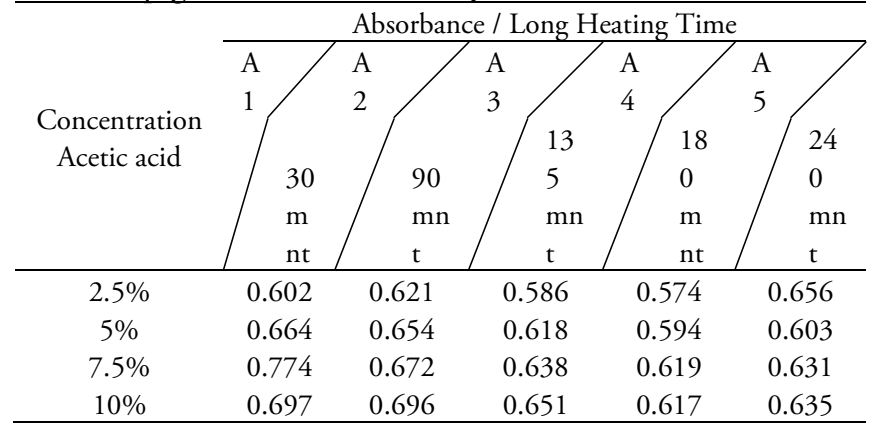

Table 6. Copigmentation of anthocyanins with acetic acid at $80{ }^{\circ} \mathrm{C}$

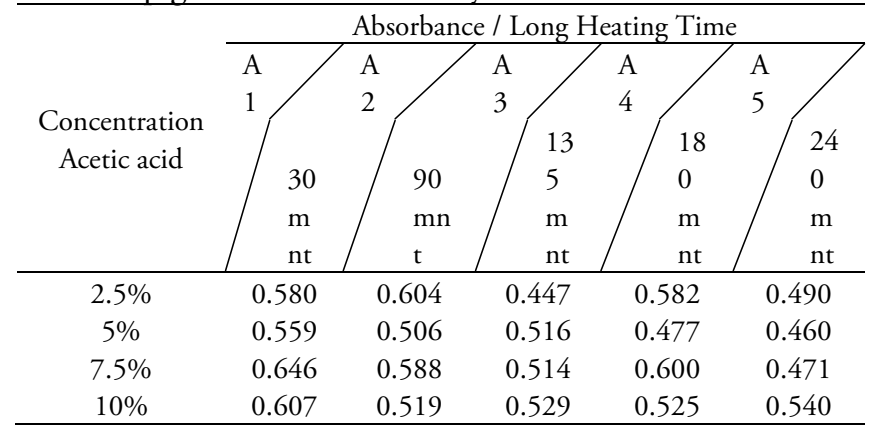

Copigmentation of jamblang fruit skin with alum

Copigmentation of jamblang fruit anthocyanins with acetic acid produces a bluishpurple solution. This is because the alum has a $\mathrm{pH}$ of 9 with an acidity degree of 8 , which is close to normal (Syafitri, 2015). According to Suardi (2005), anthocyanin is blue in alkaline media and purple in neutral media. Jamblang fruit anthocyanin copigmentation absorbance data can be seen in the Tables 7-9.

$\underline{\text { Table 7. Copigmentation of anthocyanins with alum at } 40{ }^{\circ} \mathrm{C}}$

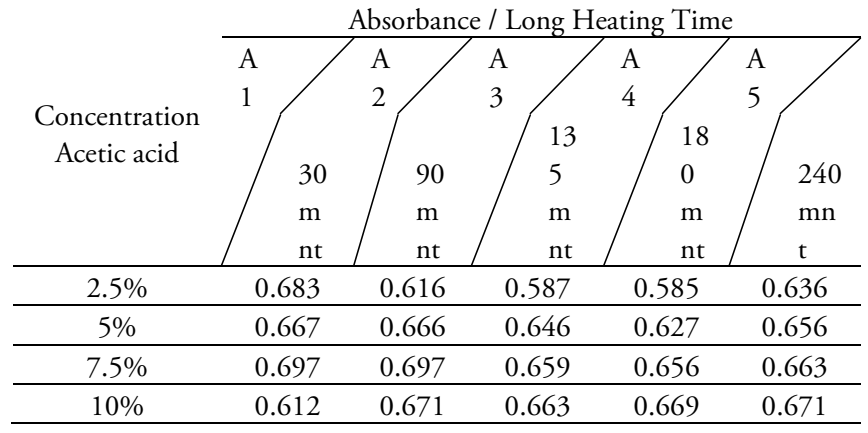

Table 8. Copigmentation of anthocyanins with alum at $60^{\circ} \mathrm{C}$

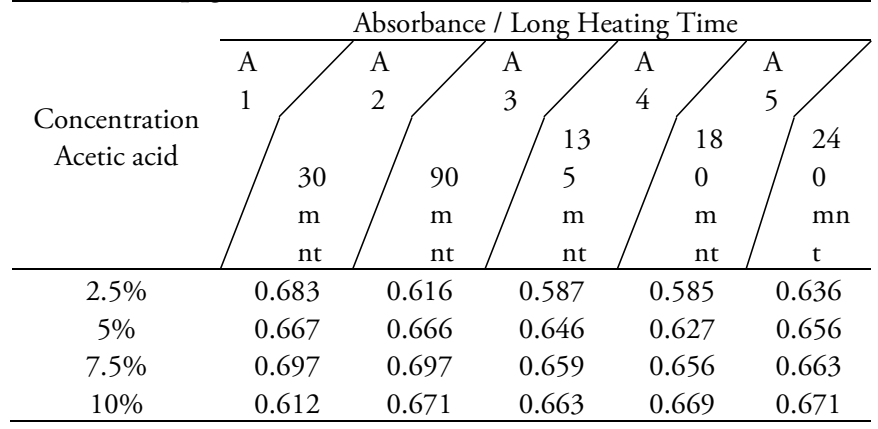


Table 9. Copigmentation of anthocyanins with alum at $80^{\circ} \mathrm{C}$

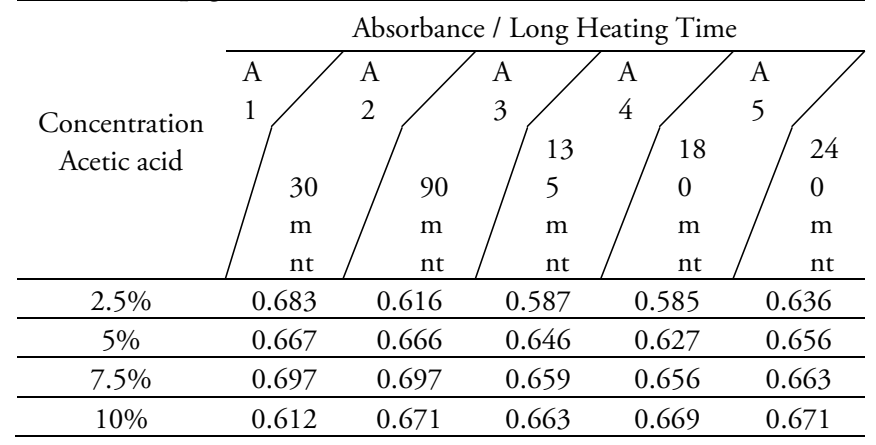

Copigmentation of anthocyanins with acetic acid and alum was carried out with various concentrations of $2.5 \%, 5 \%, 7.5 \%$, and $10 \%$. Concentration variations were carried out to see which concentration anthocyanins could maintain their stability, followed by heating at various temperatures and heating times of $80{ }^{\circ} \mathrm{C}$ for 150 minutes; every 30 minutes, absorbance measurements were taken. At a temperature of 60 ${ }^{\circ} \mathrm{C}$, heating was carried out for 225 minutes; every 45 minutes, the absorbance was measured. The temperature was $40{ }^{\circ} \mathrm{C}$, heating was carried out for
300 minutes, every 60 minutes, the absorbance was measured. Variations in temperature and heating time are based on anthocyanins' nature, easily damaged by heat during processing and storage. Lestario (2017) recommended using HTST (hightemperature short time) to reduce pigment damage.

\section{Stability test against temperature}

The temperature stability test curve of jamblang fruit anthocyanin on copigmentation with acetic acid $2.5 \%, 5 \%, 7.5 \%$, and $10 \%$ at $80{ }^{\circ} \mathrm{C}, 60$ ${ }^{\circ} \mathrm{C}$, and $40{ }^{\circ} \mathrm{C}$ can be seen in the Figures 2-4.

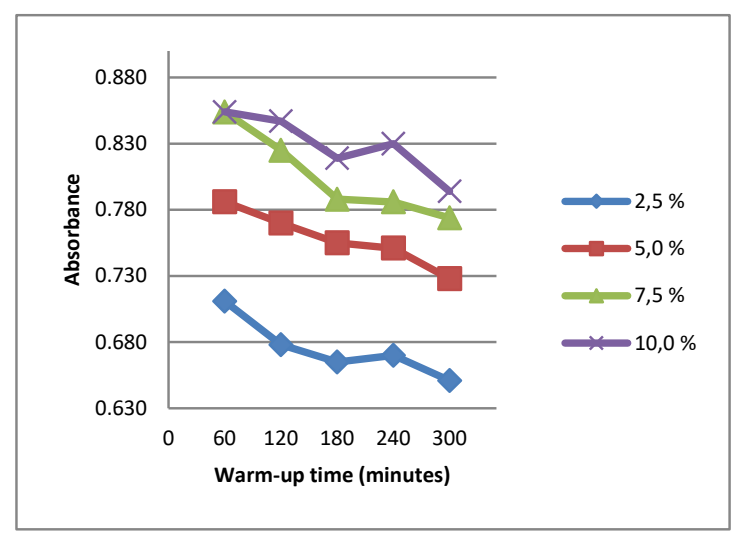

Figure 2. Graph of anthocyanin stability test of jamblang fruit extract on copigmentation with $2.5 \%$ acetic acid; $5 \% ; 7.5 \% ; 10 \%$ on heating at $40^{\circ} \mathrm{C}$.

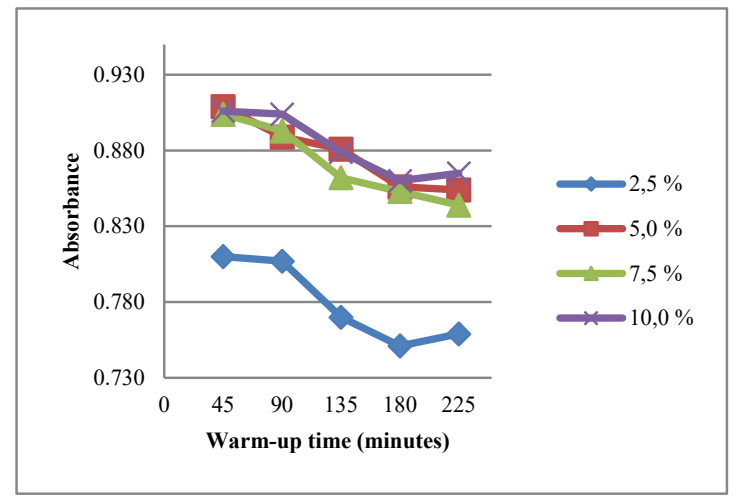

Figure 3. Graph of anthocyanin stability test of jamblang fruit extract on copigmentation with $2.5 \%$ acetic acid, $5 \% ; 7.5 \%, 10 \%$ on heating at $60{ }^{\circ} \mathrm{C}$. 


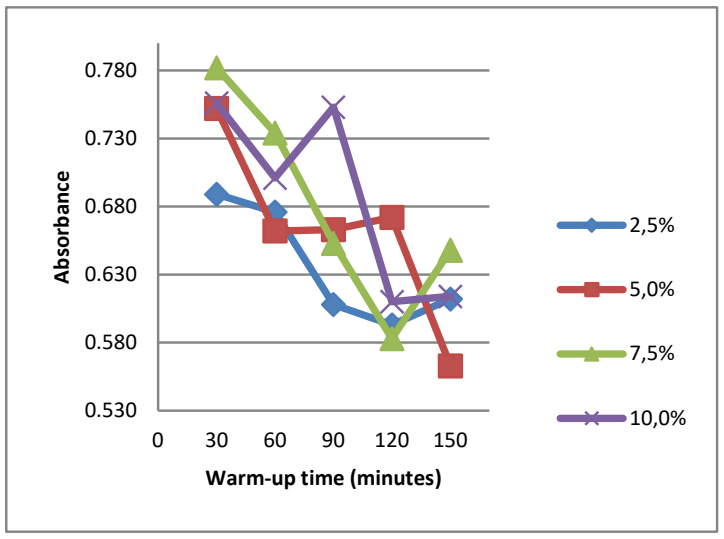

Figure 4. Graph of anthocyanin stability test of jamblang fruit extract on copigmentation with $2.5 \%$ acetic acid; $5 \% ; 7.5 \% ; 10 \%$ on heating at $80{ }^{\circ} \mathrm{C}$.

The color of the anthocyanin of the jamblang fruit copigmented with acetic acid indicates that the anthocyanin is in the form of a flavilum cation with the appearance of a red solution. The longer it is heated at high temperatures, the anthocyanin color fades to colorless. This is because anthocyanins in the form of flavilum cations undergo hydration to form a colorless carbinol base (Wulaningrum et al., 2013). Changes in the form of anthocyanins can be seen in the following mechanism (Figure 5).

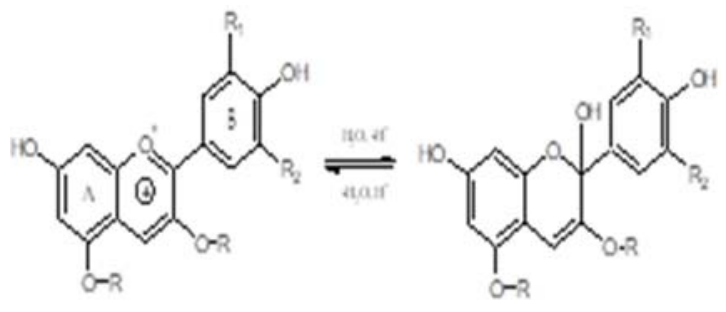

Figure 5. Changes in anthocyanin structure due to hydration.

The results of observations on the anthocyanin copigmentation stability test curve using acetic acid showed that at a temperature of $80{ }^{\circ} \mathrm{C}$ at each variation of the copigment concentration, anthocyanins were unstable. This is by research conducted by (Khuzaimah, 2018) which states that the higher the heating temperature, the lower the absorbance or color stability, so the red color will decrease. Andarwulan \& Faradilla (2012) stated that heating can cause anthocyanin equilibrium to tend towards the base form of carbinol or colorless chalcone. Damage due to heating occurs due to hydrolysis in the glycoside bonds of anthocyanins, resulting in unstable aglycones.

The temperature stability test curve of jamblang fruit anthocyanin on copigmentation with $2.5 \%, 5 \%, 7.5 \%$, and $10 \%$ alum at $80{ }^{\circ} \mathrm{C}, 60{ }^{\circ} \mathrm{C}$, and $40{ }^{\circ} \mathrm{C}$ can be seen in the Figures 6-8.

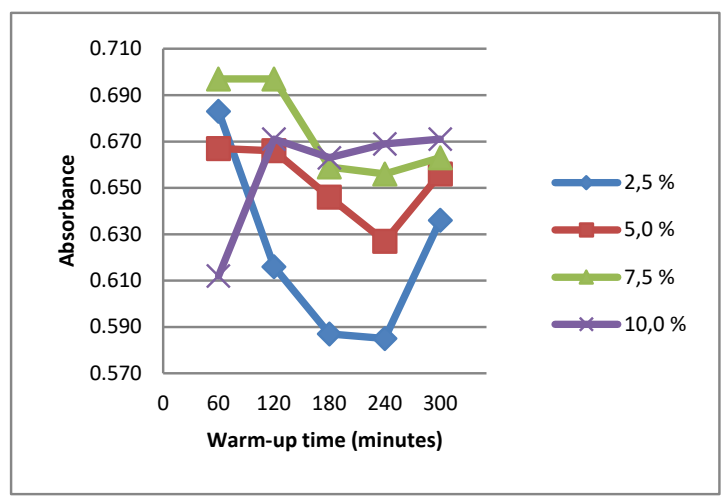

Figure 6. Graph of anthocyanin stability test of jamblang fruit extract on copigmentation with $2.5 \%$ alum; $5 \% ; 7.5 \% ; 10 \%$ on heating at $40{ }^{\circ} \mathrm{C}$. 


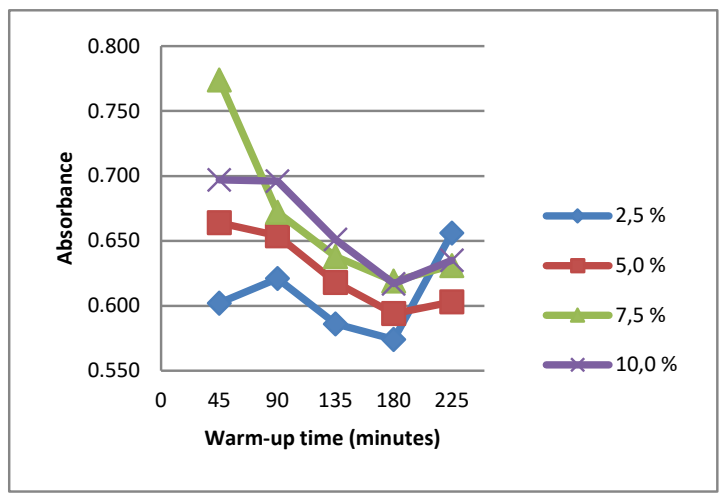

Figure 7. Graph of anthocyanin stability test of jamblang fruit extract on copigmentation with $2.5 \%$ alum; $5 \% ; 7.5 \% ; 10 \%$ on heating at $60{ }^{\circ} \mathrm{C}$.

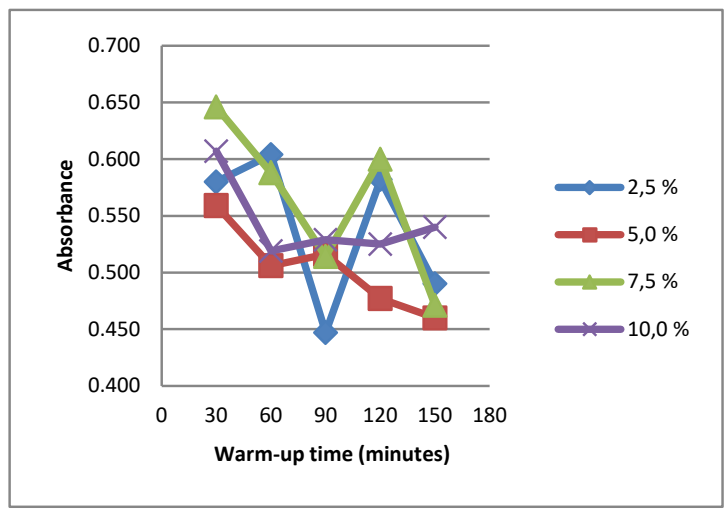

Figure 8. Graph of anthocyanin stability test of jamblang fruit extract on copigmentation with $2.5 \%$ alum; $5 \% ; 7.5 \% ; 10 \%$ on heating at $80{ }^{\circ} \mathrm{C}$.

The results of the temperature stability test for the anthocyanin extract of jamblang fruit on copigmentation with $2.5 \%, 5 \%, 7.5 \%$, and $10 \%$ alum showed that on heating at a temperature of 40 ${ }^{\circ} \mathrm{C}$ and $80{ }^{\circ} \mathrm{C}$, it was unstable. At a temperature of $60{ }^{\circ} \mathrm{C}$, anthocyanins have the highest absorption compared to heating at $40{ }^{\circ} \mathrm{C}$ and $80{ }^{\circ} \mathrm{C}$. At high temperatures, anthocyanins are damaged, which can be seen through the low absorbance value. In addition, the longer the heating time, the absorbance value also decreases (Wulaningrum et al., 2013).
Laleh et al. (2006) has studied on the effects of light, temperature, $\mathrm{pH}$, and species on anthocyanin stability in four berberis species stated that increasing temperature accelerates anthocyanin breakdown. Anthocyanin damage is caused by hydrolysis of glycoside structure.

According to Goto et al. (1976), adding salt can increase the stability of anthocyanins. This is caused by ion pairs between salt ions and anthocyanins. According to Lukas (2017) anthocyanins and alum can react according to the following equation:

$$
\mathrm{C}_{15} \mathrm{H}_{11} \mathrm{O}_{4}+\mathrm{Al}_{2}\left(\mathrm{SO}_{4}\right)_{3}+3 \mathrm{H}_{2} \mathrm{O} \rightarrow 3 \mathrm{C}_{15} \mathrm{H}_{11} \mathrm{O}_{4} \cdot 2 \mathrm{Al}^{3+}+3 \mathrm{H}_{2} \mathrm{SO}_{4}+\frac{3}{2} \mathrm{O}_{2}
$$

The interaction between anthocyanins and sodium is estimated by how $\mathrm{Na}^{+}$metal substitutes hydrogen in anthocyanins to form anthocyanin salts. While the reaction of anthocyanins with metal $\mathrm{Ca}^{2+}$ is expected to occur in the same way with $\mathrm{Na}$; but requires 2 anthocyanin compounds to bind to it according to the valence of $\mathrm{Ca}$ (Kusrini et al., 2017). Aluminum metal has a valence of 3 , requiring 3 anthocyanin compounds to form bonds. Based on this reference, the reaction between anthocyanins and metal $\mathrm{Al}^{3+}$ can be predicted as follows: 


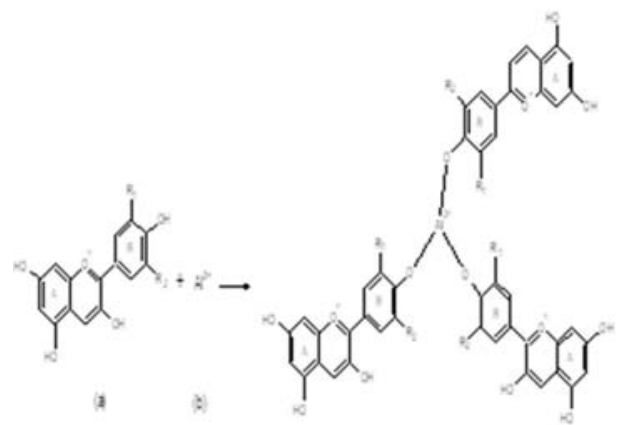

Figure 9. Estimated interaction between (a) anthocyanins and (b) metal $\mathrm{Al}^{3+}$

From this study, it can be seen that hightemperature heating of $80{ }^{\circ} \mathrm{C}$ with the shortest heating time of 150 minutes showed that copigmentation with acetic acid and alum could not maintain the stability of anthocyanins. Heating at a low temperature of $40{ }^{\circ} \mathrm{C}$ with the longest heating time of 300 minutes showed Copigmentation of the two copigments of acetic acid and alum has also not been able to maintain the stability of anthocyanins which is indicated by a decrease in absorbance, and the color fading of the extract mixed with the copigment.

This is by the research conducted by (Sari et al., 2005). The results showed that the anthocyanins of Duwet fruit at medium temperature (40 and 60 ${ }^{\circ} \mathrm{C}$ ) were able to maintain color stability above $80 \%$. In comparison, at high temperatures (80 and 100 $\left.{ }^{\circ} \mathrm{C}\right)$, the color stability of anthocyanins decreased drastically to below $20 \%$ for 4 hours of heating.

\section{Conclusions}

The conclusion that can be drawn from this study is that the higher the heating temperature of the anthocyanin of the jamblang fruit copigmented with acetic acid and alum, the lower the stability of the anthocyanin pigment and the longer the heating time for the anthocyanin copigmented with acetic acid and alum, the lower the stability of the anthocyanin pigment.

\section{Acknowledgment}

The authors would like to thank all those who have helped the author in completing this research.

\section{References}

Andarwulan, N., \& Faradilla, R. H. F. (2012). Pewarna alami untuk pangan. South East Asian Food and Agricultural Science and Technology (SEAFAST) Center. Bogor: IPB.

Ashari, H. (2010). Ekstraksi dan karakterisasi antosianin dari ubi banggai maku makulolong. Unpublished undergraduate's thesis. Palu: Universitas Tadulako.

Azura, S. L., Sutri, R., \& Iriany. (2015). Pembuatan etil asetat dari hasil hidrolisis, ermentasi dan esterifikasi kulit pisang raja (musa paradisiaca l.). Jurnal Teknik Kimia USU, 4(1), 1-6.
Basuki, N., Harijono., Kuswanto., \& Damanhuri. (2005). Studi pewarisan antosianin pada ubi jalar. Agravita, 27(1), 63-68.

Boulton, R. (2001). The copigmentation of anthocyanins and its role in the color of red wine: A critical review. American Journal of Enology and Viticulture, 52(2), 67-85.

González-Manzano, S., Dueñas, M., RivasGonzalo, J. C., Escribano-Bailón, M. T. \& Santos-Buelga, C. (2009). Studies on the copigmentation between anthocyanins and flavan-3-ols and their influence in the colour expression of red wine. Food Chemistry, 114(2), 649-656.

Goto, T., Hoshino, T., \& Ohba, M. (1976). Stabilization effect of neutral salts on anthocyains: flavilium salts, anhidrobase and genuine anthocyanins. Journal Agricultural Biological Chemistry, 40(8), 1593-1596.

Harborne, J. B. (1987). Metode fitokimia. Bandung: ITB Press.

Ibnu., K, Erlidawati., \& Munzir. (2013). Kestabilan zat warna alami dari umbii ketela ungu (Ipomoea Batatas). Jurnal CDA, 1(1), 34-40.

Khuzaimah, S. (2018). Uji stabilitas pigmen hasil ekstraksi zat warna alami dari kulit buah naga (hylocereus undatus). Jurnal Teknologi Industri, 2(2), 1-10.

Kristiana, H. D., Setyaningrum, A., \& Lia, U. K. (2012). Ekstraksi pigmen antosanin buah senggani (melastoma malabathricum auct. non linn) dengan variasi jenis pelarut. Jurnal Teknosains Pangan, 1(1), 105-109.

Kusrini, E., Dewi, T., \& Ni'matul, I. (2017). Uji aktivitas bunga telang (clitoria ternatea 1.) sebagai agen anti katarak. Jurnal Jamu Indonesia, 2(1), 30-36.

Laleh, G. H., Frydoonfar, H., Heidary, R., \& Jameei, R. (2006). The effect of light, temperature, $\mathrm{pH}$, and species on stability of anthocyanin pigments in four berberies spesies. Pakistan Journal of Nutrition, 5(1), 90-92.

Lee, J., Durst, R. W., \& Wrolstad, R. E. (2005). Determination of total monomeric anthocyanin pigment content of fruit juices, beverages, naturalcolorants, and wines by the $\mathrm{pH}$ differential method: Collaborative study. 
Journal of AOAC International, 88(5), 12691278.

Lestario, L. N. (2017). Antosianin sifat kimia, perannya dalam kesehatan, dan prospeknya sebagaii pewarna makanan. Yogyakarta: Gajah Mada University Press.

Lestario, L. N., \& Silvia, A. (2016). Kopigmentasi kuersetinapel (pyrus malus) terhadap stabilitas warna ekstrak buah duwet (syzygium cumini). Prosiding Konser Karya Ilmiah (pp 37-42). Salatiga: Fakultas Pertanian dan Bisnis, Universitas Kristen Satya Wacana.

Lukas, S.G.A. (2017). Pengaruh proses fiksasi terhadap kualitas warna kain sutera pada pemanfaatan antosainin hasil ekstraksi kulit buah naga. Skripsi Tidak Diterbitkan Samarinda: Universitas Politeknik Negeri.

Munawaroh, H., Ganjar, F., Liya, L. N. M. Z. S., Qonita, A. H., Rahmat, H., \& Sayekti, W. (2015). Kopigmentasi dan uji stabilitas warna antosianin dari isolasi kulit manggis (garcinia mangostana 1). Prosiding Seminar Nasional Matematika, Sains dan Informatika (pp 321329). Surakarta: Fakultas Matematika dan Ilmu Pengetahuan Alam, Universitas Sebelas Maret.

Nugraheni., \& Mutiara. (2014). Pewarna alami sumber dan aplikasinya pada makanan dan kesehatan. Yogyakarta: Graha ilmu.

Nuryanti, S., Sabirin, M., Chairil, A., \& Tri. J. R. (2012). Isolation anthocyanin from roselle petals (hiniscus sabdariffa l) and the effect of light on the stability. Indonesian Journal of Chemistry, 12(2), 167-171.

Nusantara, Y. P., Lydia, N. L., \& Yohanes, M. (2017). Pengaruh penambahan asam galat sebagai kopigmen antosianin murbei hitam (morus nigra. 1) terhadap stabilitas termal. Agritech, 37(4), 428-436.

Sari, P., Fitriyah, A., Mukhamad, K., Unus., Mukhamad, F., \& Triana, L. (2005). Ekstraksi dan stabilitas antosianin dari kulit buah duwet (syzygium cumini). Jurnal Teknologi dan Industri Pangan, 16(2), 142-150.

Siswoyo, R. (2009). Kimia organik. Jakarta: Erlangga.

Suardi, D. (2005). Potensi beras merah untuk peningkatan mutu pangan. Jurnal Litbang Pertanian, 24(3), 93-100.

Supiyanti, W., Endang, D.W., \& Kusmita, L. (2010). Uji aktivitas antioksidan dan penentuan kandungan antosianin total kulit buah manggis (Garcinia Mangostana 1). Majalah Obat Tradisional, 15(2), 64-70.

Sutharut, J., \& Sudarat, J. (2012). Total anthocyanin and antioxidant activity of germinated colored rice. International Food Research Journal, 19(1), 215-221.

Syafitri, R. (2015). Perbedaan perbandingan larutan celup (vlot) terhadap hasil pencelupan bahan sutra menggunakan ekstrak kelopak bunga rossela (bibiscus sabdariffa l) dengan mordan tawas $\left(\mathrm{Al}_{2}\left(\mathrm{SO}_{4}\right)_{3}\right)$. Unpublished undergraduate's thesis. Padang: Universitas Negeri Padang.

Utomo, S. (2016). Pengaruh konsentrasi pelarut (nheksan) terhadap rendemen hasil ekstraksi minyak biji alpukat untuk pembuatan krim pelembab kulit. KONVERSI, 5(1), 39-47.

Wrolstad, R. E., Durst, R. W., \& Lee, J. (2005). Tracking color and pigment changes in a anthocyanin products. Elsevier, 16(9), 423-428.

Wulaningrum, R. A., Wisnu, S., \& Mohammad, A. (2013). Pengaruh asan organik dalam ekstraksi zat warna kulit buah manggis (garcinia mangostana). Indonesian Journal of Chemical Science, 2(2), 120-124.

Zulfajri, M. \& Muttakin. (2017). Metode ekstraksi antosianin dari kulit buah syzygium cumini (1.) skeels sebagi indikator alami asam basa. Prosiding Seminar Nasional II USM Eksplorasi Kekayaan Maritim Aceh di Era Globalisasi dalam Mewujudkan Indonesia sebagai Poros Maritim Dunia (pp 547-553). Aceh: Universitas Serambi Mekkah. 